\title{
Nancy Fraser: Revolutionary Empiricism?
}

\author{
Jørgen Sandemose \\ Department of Philosophy, Classics, History of Art and Ideas (IFIKK), \\ Oslo University, Norway \\ E-mail: jorgen.sandemose@ifikk.uio.no
}

Received: August 9, 2015 Accepted: August 30, 2015 Published: December 4, 2015

doi:10.5296/jsss.v3i1.8676

URL: http://dx.doi.org/10.5296/jsss.v3i1.8676

\begin{abstract}
This article presents a criticism of Nancy Fraser's influential essay "Behind Marx's Hidden Abode. For an Expanded Conception of Capitalism". After a short introduction determining Fraser's theoretical stance amidst the critical waves around Karl Marx's positions, her concept of "abodes", thought to be hidden from Marx's view of the capitalist order, is analyzed. Thereupon, certain limitations of her interpretation of the "economic" dimension in Marx's work is pointed out, and also how they lead to misconceptions of the theory of the social formation as a whole. Furthermore, it is shown how Fraser is tempted to introduce ill-considered and alien elements into Marx's view of the international economy (the world market), thereby rendering meaningless a Marxian concept of the political. Towards the end, the distinctively empiricist aura in which Fraser's theory is presented is being criticized: It represents a rupture with any possible revolutionary theory.
\end{abstract}

Keywords: Misplaced Feminism, Hidden Abodes in Marx's Accumulation, Marx contra Sraffa

\section{Introduction}

Along with an impressive number of forerunners, among which Jürgen Habermas, Talcott Parsons, and Niklas Luhmann are the perhaps most renown, Nancy Fraser wants to correct Karl Marx's picture of capitalist society - first by eulogizing his insights, and then, predictably, by splitting his totalizing picture of the social world into a plurality of subordinate fields of life and action. Swathing his theory in garniture fitted for a life in ultra-modern salons, she searches for a definition of " $21^{\text {st }}$-century capitalism" (Fraser 2014, 61.) (Note 1).

Still, she does claim that "Marx looked behind the sphere of exchange, into the 'hidden abode' of production, in order to discover capitalism's secrets" (Fraser, 57).This rather unprecise wording she leads into a rectifying of Karl Marx with the neo-Ricardian Piero Sraffa and the latter's well-known work Production of commodities by means of commodities 
(1960), a title which Fraser finds very well adapted as a description of the system Marx presents.

These are misunderstandings which place Fraser in yet another generation of not too well-informed ideologists from which she claims to distance herself. Actually, despite her evident indebtedness to them, she goes as far as calling them "younger activists and scholars [who] have become sophisticated practitioners of discourse analysis while remaining utterly innocent of the traditions of Kapitalkritik" (Fraser, 55).

That may be so, but what then of Fraser's Marxisant endorsement of the overarching principle of Sraffa's system, which in every way breaks with the fundamentals in Marx, and is free from any explanation of production, conserving and transfer of values between trades? Let us expand in some measure on that subject.

\section{Fancies of "Epistemic Shifts" and "Hidden Abodes"}

Fraser declares that she wishes to penetrate past Marx's abode, the industrial factory realm with its secrets, and "seek production's conditions of possibility behind that sphere, in realms that are more hidden still".

How these realms are to be identified, is to some extent clarified by the author's comments on a certain mode of struggling against the capitalist order, among them the following ones:

For example, some opponents of neoliberalism draw on ideals of care, solidarity and mutual responsibility, associated with reproduction, in order to oppose efforts to commodify education. Others summon notions of stewardship of nature and justice between generations, associated with ecology, to militate for a shift to renewable energy (Fraser 68).

And she comments as follows:

Such claims, along with the counter-claims they inevitably incite, are the very stuff of social struggle in capitalist societies - as fundamental as the class struggles over control of commodity production and distribution of surplus value that Marx privileged (Fraser, 68).

In the same vein, one of her aims is said to be

... implicating multiple axes of inequality, including nationality/race-ethnicity, religion, sexuality and class. In this respect, too, however, our received theoretical models fail us, as they continue to privilege struggles over labour at the point of production (Fraser, 56).

Indeed, if Marx had privileged such struggles over "labour", a sensible reader would have had relatively few critical objections to Fraser's criticism of him.

But of course, he did not. The main thrust of Marx's Hauptwerke, taken in its relation to working class action, is his argument to the effect that capital accumulation leads to the will to overthrow commodity production in general; furthermore, the logical outcome is a settling of accounts with the existence of surplus value in general, and to generate its sublation.

Naturally, on the way to these goals, workers will have to give the opposition to the system a limited and purely temporary content, possibly resulting in just as temporary a control over certain factory conditions or periodically successful appropriation of streams of surplus to progressive tasks - all of which could be taken to be "struggles over labour at the point of production".

Fraser, limiting her perspective to such phenomena, is quite right in putting proletarian 
workers' action on the same footing, and not above, other struggles which she applauds.

However, as already implied: She is unaware of certain structures that necessarily make it a social constant that the immediate struggle between capital and wage labour will overdetermine other overt contradictions and the formation of other class and group interests in bourgeois society. Thus Fraser's point of departure is misconceived. To back up this contention, let us see how she connects the endorsement of Sraffa with her view of the market institution:

...capitalism ... uses them [i.e. markets] to allocate real estate, capital goods, raw materials and credit. Insofar as it allocates these productive inputs through market mechanisms, capitalism transforms them into commodities. It is, in Piero Sraffa's arresting phrase, a system for the 'production of commodities by means of commodities' (Fraser, 58).

This passage is duly spiced with subsidiary howlers (allocation of goods through circulation presupposes that they are commodities, credit is not a productive input, neither is real estate, etc.), but let us concentrate on the main pitfall: Fraser's rectifying of Marx with Sraffa.

Indeed, to Marx, capitalist production is precisely the opposite of a production by means of commodities. For the very "allocation" of goods for productive purposes mentioned by Fraser, structurally leads to a "decommodification" of the products in their entering the sphere of production.

To illustrate, let us take a well-known example: In buying a bottle of wine, I recognize and acknowledge its former owner as a Warenbesitzer, and am myself recognized by the seller: I am a person with acknowledged needs! But as I open the bottle, it (and the wine) is torn out of circulation and has consequently no commodity character. Drinking, or any consumption whatever, is not a fact of circulation. Consumption of any useful product (use value) is the destruction of the product.

The industrial capitalist is a historical descendant of merchant capital and can copy the recognizing actions of the wine merchant: In buying commodities such as 'capital goods, raw materials' (vide Fraser) and posit them at a workplace, he transforms them into products pure and simple. For they are now to be worked upon, and as such cannot be employed as exchange values, only as use values. Also, he has bought labour power, a commodity, and brought it live and cicking through the fence marked 'No admittance except on business'. The first thing to do, is to put it to work. But then labour power is transformed to labour, which can least of all be called a commodity, and on the contrary is the creator of both value and use value. It is decommodified. 'Production by means of commodities', indeed!

The crucial importance of these facts for seeing through Fraser's contentions, should be evident. She is after some "hidden" abodes. But a measuring rod for the status of being "hidden" is that it is outside of the factory "abode". That is what Fraser must mean. And since she has a limited concept of what this latter abode looks like, she cannot fully know for certain where, or outside of what, she should seek.

Fraser takes up Marx's theses on capital's turning into a subject in bourgeois production. She even says she adheres to it: "Marx is brilliant on this point" (Fraser, 58). She correctly labels it 'self-expanding value' (cf. Fraser, 57). On the other hand, she dissociates herself from Georg Lukács's Geschichte und Klassenbewusstsein (1923). She in fact justifies her theory of 
new, hidden abodes with a polemic against Lukács's essay on 'Reification and the Consciousness of the Proletariat', where, she says, 'the commodity form colonizes all of life, stamping its mark on such diverse phenomena as law, science, morality, art and culture" (Frazer, 66). And she adds: 'In my view, commodification is far from universal in capitalist society." Indeed it is not.

Evidently, Lukács's argument cannot be refuted with the means at Fraser's hand. It is de facto closely knitted to Marx's theory of reproduction, which she does not keep duly present. In fact, why is the commodity form taken as colonizing? Well, because, the "wealth of the societies in which capitalist mode of production rules, appears [erscheint] as a monstrous collection of commodities" (cf Marx 1969, 49, italics added). We see those "elementary forms", these individualized commodities, everywhere outside their actual production. To that extent, they dominate our perspective totally, and even so-called pure nature appears to us $s u b$ specie mercium. What is more, we see them as our own products, and have to realize that the monstrosity in some way stems from ourselves. That oblique sort of consciousness is part of capital reproduction itself. It is an aspect of "capital as subject".

However, no subject can come about if there is not an object to be found. Capitalist production is based on a topsy-turvy of natural relations: While it depends on the expropriation of the workers from property, it has to replace this expropriation with a unification inside the production process, since otherwise no labour could be performed. The 'natural' relation between worker and means of labour and raw materials is instituted again, but only inside the factory gates, and only on condition of the formal, and, in due course, the real subsumtion under capital - subsumptions that are precisely the fundamental representation of capital as dominating subject. Nature itself appears as a spectre generated by exchange between capital and labour. That is result of the expropriation of the worker from constellations of landed property.

Still, for Fraser, this expropriation cannot be taken to represent the whole story. She introduces quite a special concept of "social reproduction":

Arguably, however, there are other, equally momentous epistemic shifts which are implied in Marx's account of capitalism but not developed by him. These moves, to abodes that are even more hidden, are still in need of conceptualization. They need to be written up in new volumes of Capital, if you like, if we are to develop an adequate understanding of 21 st-century capitalism. One is the epistemic shift from production to social reproduction the forms of provisioning, caregiving and interaction that produce and maintain social bonds (italics added).

And she goes on:

Structurally, moreover, the division between social reproduction and commodity production is central to capitalism-indeed, is an artefact of it. As scores of feminist theorists have stressed, the distinction is deeply gendered, with reproduction associated with women and production with men (Fraser, 61-62).

Having thus laid a base for the introduction of "feminism" as a "momentous" aspect of a Capital for our century, Fraser underscores that this "social-reproductive activity is absolutely necessary to the existence of waged work, the accumulation of surplus value and the 
functioning of capitalism as such" (Fraser, 61).

But this idea of a basal feminism is nothing but a beaten track to empiricism. Firstly, capitalism has never been subject to such an "epistemic shift". On the contrary, it belongs intimately to the features of capital that it reproduces itself in an overdetermined and immanent manner:

The capitalist process of production, taken in its coherence or as process of reproduction, ... produces not only commodities, not only surplus value, it produces and reproduces the capital relation itself, on the one side the capitalist, on the other the wage worker (Marx, 1969 (1867)), 603).

How does this reproduction go on? Precisely filtered through the conditions we described above: The split proletarian consciousness is the point of departure in the "social reproduction". In so far as he is posited vis-à-vis a given thing, and thus establishing his consciousness as an objective one, he has to meet that thing as a commodity, and as each and every subject in capitalist society, his consciousness is as such inclined to posit the commodity form as the form of the thing as such.

These sorts of things have in principle been produced by himself, and since that is also part and parcel of his consciousness, the "capitalist process of production" produces itself and its own conditions over and over again.

Now, if Fraser would want to negate the priority of this process, and rather hold fast the "absolute necessity" of the "provisioning and caregiving", then she would have to give up her adherence to Marx's "brilliant" analysis of the capital as "subject" and self-expanding exchange value. For this consists in nothing other than the form of perpetuating the wage-worker's existence as such. Not only is he, in Marx's view, being tied to capital with a "golden chain" through the necessary illusions pertaining even to the simple reproduction of capital, but the weight of the chain will augment pari passu with the accumulation of this capital. This process functions - together with the price of soil rising in a parallell movement with the accumulation - as a repetitive guarantee for the conservation of the system and consequently for the renwal of the statuses as capitalist and wage-worker. Fraser's error implies forgetting that no care and provision can guarantee that these characters, roles and functions are kept in place. There is little use for the capitalist system in offering "care" as long as a person is not there, together with his character-mask. It is the reproduction of the capital relation that ensures the continued existence of a wage-worker. It is not even a question of keeping specific human beings alive to be cared for. What needs to be reproduced, is these human beings in their form of wage-workers, capitalists and modern landowners.

Fraser, on the contrary, insists that one special activity,

[v]ariously called 'care', 'affective labour' or 'subjectivation', ... forms capitalism's human subjects, sustaining them as embodied natural beings, while also constituting them as social beings, forming their habitus and the socio-ethical substance, or Sittlichkeit, in which they move" (Fraser, 61).

This is impossible as a basic description; what happens in such an activity, is only the outer realization of the formation of subjects through captalist production. To endorse it in this theoretical investigation is to bow to empiricism, since it implies confounding humans in 
their isolated physical appearance with men qua persons in social interaction. What should be sought for is not "care", but the overarching social movement.

\section{Misconceptions of the Content of Marx's "Economic" Critique}

The methodological misconceptions from Fraser's side consequently seem to stand forward in a clear light. In addition, it should be underscored how they indicate a non-historical approach to class relations tout court.

In diverse ways, Fraser uses her article to underbuild a contention to the effect that a specific difference between gender-roles is characteristic to capitalism. This functions like a maneuver aiming to show precisely the privileged position of her concept of "social reproduction". Actually, she writes:

Far from being universal, then, the division between production and reproduction arose historically, with capitalism (Fraser, 62).

Which is fortified by this thesis:

Much like 'original accumulation,' therefore, social reproduction is an indispensable background condition for the possibility of capitalist production (Fraser, 61).

Without mustering adequate specification, Fraser explains this development with a "break-up of a previous world". However, which world? - It is clear that the thesis can be said to be in harmony with the situation typical of very important segments of Western European feudal society, where wife and husband of the serf-class could make out economically co-working households, producing cloth outside the feudal jurisdiction, i.e. operate with commodities and make up the perhaps most important element in the creation of an inner market which was a prerequisite of a capitalist order. Thus it is an interesting question to decide whether capitalism proper, as it broke through and had to sublate feudal society, was also forced to destroy such economic units, and replace a harmonic wife-husband-relation with some form of antagonism.

However, it is out of the question to argue that such a relative harmony was present e.g. in the Greco-Roman-Hellenistic world. In a slave economy, such harmonies were certainly absent from most of society - be it on the slave-side, be it among slaveholders. If we turn to the Asian social formation, societies with an "Asian mode of production" (still very influential all over the so-called "third world"), such a relation between family and wider society seems not to be viable. In conclusion, if Fraser means to say that the "separation" in question is in any way specific for capitalism, she is simply wrong. And if so, one should also contemplate the fact that the use of the separation as an auxiliary argument for a historical specificity of the capitalist order, on a par with the uniqueness of a mode of production that operates as a "self", generated from a unique expropriation of the kind we saw in Tudor times, is questionable.

A central reason for introducing this last point, is the fact that Fraser is unclear as to whether tendencies to a globalization of the economy of capitalist nations result in a world which as a whole should be called "capitalist". This lack of clarity is all the more difficult to tolerate, since Fraser is at least just as unclear when it comes to the question of whether the strong separation between politics and economy, which she rightly ascribes to capitalist nations, is now valid also for countries in the "third world". In fact, it would be extravagant to fasten such a label on countries such as Egypt, Russia or China. The separation in question is rather 
a product of capitalist eco-social relations only (general alienation of the producers from means of production). Furthermore, this makes it obsolete to operate with "political power" as a separate force enabled to function separately on line with the "economy". Rather, the economic base keeps politics at bay and operates without being disturbed, only by being reinforced, by the state body. Below, we shall return to this theme.

In fact, Fraser consistently describes the capitalist social formation in a way that is incompatible with the dynamics of capital as a "self". And as the time comes, she admits as much herself. Capitalism, she eventually tells us,

is best conceived as an institutionalized social order, on a par with, for example, feudalism. Understanding capitalism in this way underscores its structural divisions, especially the institutional separations that I have identified. Constitutive of capitalism, we have seen, is the institutional separation of 'economic production' from 'social reproduction', ...(Fraser, 67).

There is of course an absolute break in this alleged consistency: No such social system can be combined with a dominant mode of production with subjective force, and consequently the theme which, according to Fraser herself, attracted her to Marx, must disappear entirely.

It is of interest that the definition of capital which Fraser ends up with in the moment she gives her own version of what it means that it is a self-expanding value, is, as we have seen already, a classical reformist one. She takes this expanding value to be an entity on which revolutionary action will be irrelevant. Consequently, it stands to reason to suppose that it is her aim (possibly malgré elle) to find a non-revolutionary solution of the different structural conflicts in the system, such as ecological crises and gendered repression connected to household and "care".

However, such fields are interconnected with the overdetermining self-expanding capital value, and in quite another fashion that Fraser imagines. Her aims will be utopian without a revolutionary line for overthrowing of basic property relations. They cannot even be put on the agenda without such a point of departure.

Those aims come to the fore in the following programmatic sentences:

To understand capitalism, ..., we need to relate its front-story to ... three back-stories. We must connect the Marxian perspective to feminist, ecological and political-theoretical perspectives - state-theoretical, colonial/postcolonial and transnational (Fraser, 66).

We have now explored into the feminist abode as it is presented by Fraser. Let us turn to the ecological one. The same structural difficulties will appear in Fraser's argument.

The following gives an indication:

Unlike the land enclosures Marx ... wrote about, which 'merely' marketized already existing natural phenomena, the new enclosures penetrate deep 'inside' nature, altering its internal grammar (Fraser, 64).

Here, let us underscore two things: First (1), what Fraser calls "land enclosures" is in reality at the same time an expropriation of the Landvolk from the soil. As such, the expropriation which took place in Western Europe (with violence in Britain, resulting in repercussions on the Continent, mediated by advanced economic interaction between nations, Napoleonic Wars spreading the French bourgeois revolution, and unprecedented population growth) is unique to this day. Second (2), it generated the definitive form of private property both to 
manufacturing and to land, to an extent as yet unseen, and followed up by of the property institutions instigated by British emigrants overseas. That is, these historic events created the new type of proletarian worker, the "Wage Labour" opposed to "Capital". It put capital in the position to conquer human labour on a par with outer nature.

Let us consider some interesting results of these events, relating to the real appearance of capital as self-expanding value, ignored by Fraser.

As a conclusion of his long analysis of the typical forms of "production of relative surplus value" in the first volume of Capital, Marx presents some passages which point out the continuing psycho-physical conditions of the workers who are the direct victims of the industrial revolutions in the wake of the expropriation. Then, with a point of departure in the rise of towns as "great centres", he adds:

This has two results. On the one hand it concentrates the historical motive force of society; on the other hand, it disturbs the metabolic interaction (Stoffwechsel) between man and the earth, i.e. it prevents the return to the soil of its constituent elements consumed by man in the form of food and clothing; hence it hinders the operation of the eternal natural condition for the lasting fertility of the soil.... But by destroying the circumstances surrounding this metabolism...it compels its systematic restoration as a regulative law of social production, and in a form adequate to the full development of the human race.... All progress in capitalist agriculture is a progress in the art, not only of robbing the worker, but of robbing the soil; all progress in increasing the fertility of the soil for a given time is progress towards ruining the more long-lasting sources of that fertility.... Capitalist production, therefore, only develops the technique and the degree of combination of the social process of production by simultaneously undermining the original sources (Springquellen) of all wealth - the soil (Erde) and the worker (Marx, 1969, 523-29).

Reflections such as these are now becoming commonplace among students of Marxian thought, thanks to writings of John Bellamy Foster and others, working in the wake of German Marxisant literature from the 1960's (Note 2). It is remarkable that in spite of this, Fraser maintains that Marx's revolutionary theory in Capital was thought out in abstraction from human altering of nature's "internal grammar". The only excuse for such a limited interpretation of Marx's handling of the theme, would be that Fraser is unaware of the integration of it into his 'critique of political economy' proper. We shall have a look at this. But let us first cast a glance at another passage in Fraser's work:

Nature here is made into a resource for capital, one whose value is both presupposed and disavowed. Treated as costless in capital's accounts, it is expropriated without compensation or replenishment and implicitly assumed to be infinite. Thus, nature's capacity to support life and renew itself constitutes another necessary background condition for commodity production and capital accumulation (Fraser, 63).

As already implied: it is simply a grandiose failure to believe that such arguments are not to be found in midst of Marx's economic theory. In order to show this, certain points taken from his exposition of the starting point of accumulation are sufficient.

Toward the end of Chapter 22 of Kapital I, "Transformation of surplus value into capital", Marx offers, in the fourth section, a ten pages long reflection of "circumstances which 
independently of the proportional division of surplus-value into capital and revenue, determine the extent of accumulation". Here, he explores consequences for labour power (the worker) of the rising intensity of labour, as well as of its growing productivity, and "the growing difference in amount between capital employed and capital consumed" (Note 3).

The "difference" mentioned is common to all capitalist production, even the one that uses means of labour that are only faintly more durable than the raw materials. It means that part of the means of labour contribute to the creation of the product without contributing to its value. This fact, which in itself is a measure for the incongruence between human production of use values (a sempiternal necessity of nature) and its capitalist (value) form, has been taking on giant proportions in capitalism after 1860. It is, in fact, nothing but a case of capitalist exploration of natural forces without compensation, since means of labour are only modified nature, generating conditions for natural forces and powers (Note 4).

But this dynamic in capitalist production goes far beyond such barriers. For in fact, the very transfer of values from products of earlier labour to new products of labour, a fact that capitalists love to ascribe to a mystical force in capital-value itself (and which bourgeois economists never thematize), is nothing but a natural phenomenon acquired free of charge: It goes back to the fact that the use value of the material factors of production are transferred to the new use value of the finished product. In the same way as capital acquires the use-value creating force of the worker to create exchange-value, so it acquires the same force to transfer those exchange-values.

Fraser's thesis to the effect that Marx overlooks the sigificance of costless effects of nature, is all the more senseless. Capitalist production is even, as seen here, immediately dependent on them, and that forms a central argument in the whole of Marx's critique.

But now, in the exploration of accumulation, Marx concentrates on more mediate results. In the midst ot the exploration, he notes the following:

General result: by incorporating with itself the two primary creators (Urbildner) of wealth, labour-power and soil (Arbeitskraft und Erde), capital acquires a power of expansion that permits it to augment the elements of its accumulation beyond the limits apparently fixed by its own magnitude, or by the value and the mass of the means of production which have already been produced, and in which it exists (630-631) (Note 5).

This arresting "result" is acquired through analysis of the stages in modern extractive industry, and also agricultural production, where "the same quantity of labour" without rising the dimensions of variable capital, "performed by the same number of workers as before, ... increases the fertility of the land"; furthermore, in industry proper, every additional expenditure of labour presupposes a corresponding additional expenditure of raw materials, but not necessarily of instruments of labour. And as extractive industry and agriculture supply manufacturing industry both with its own raw materials and with those for its instruments of labour, the additional product provided by extrac- tive industry and agriculture without any additional advance of capital also redounds to the advantage of manufacturing industry (630, italics added).

Also, devastating for Fraser's polemic, are the following phenomena of capital accumulation: 


\section{MInstitute ${ }^{\text {Mink }}$}

[i]n the extractive industries, mines etc., the raw materials do not form part of the capital advanced. The object of labour is in this case not a product of previous labour, but something provided by nature free of charge, as in the case of metals, minerals, coal, stone, etc. Here the constant capital consists almost exclusively of instruments of labour which can very easily absorb an increased quantity of labour (day and night shifts, for example). All other things being equal, the mass and value of the product will rise in direct proportion to the labour expended. As on the first day of production, the two original agencies working to form the product, man and nature, continue to co-operate, and now, as creators of the products, they are also creators of the material elements of capital. Thanks to the elasticity of labour-power, the domain of accumulation has extended without any prior increase in the size of the constant capital (italics added).

These points accentuate how capitalist expropriation is certainly not confined to some 'merely marketizing enclosures' (quelle idée!), nor even to the unique Western-Tudorian expropriation of the Landvolk; it is eo ipso an expropriation of the totality of the subject-object relation - the whole of "nature" in the most eminent sense, as it was developed by the German Idealism so dominant in forming Marx's intellectual background. Capital coerces both humanity and nature, the working power and intensity of the one, the forever untamed forces and receptivities of the other, to form an effective unity.

Marx now also underlines how the general social progress in science and technology - a consequence of the new, effective unity - gives capital a platform from which it can raise labour productivity, which itself belongs to nature, free of charge, and also raise the opportunity of capital to produce "both more product-creating agencies and more value-creating agencies, in other words absorbers_of labour (Arbeitssauger)". For this is one of the basic functions of any piece of processed use value in this society; sub specie mercium, they are there to be able to suck up labour, and this very function capital can acquire to a relatively lesser cost. A fortiori, e.g.,

[e]very advance in chemistry not only multiplies the number of useful materials, and the useful applications of those already known, thus extending capital's sphere of investment along with its growth; it also teaches capital how to throw back the waste from the processes of production and consumption into the cycle of the process of reproduction, and thus, without any previous outlay of capital, it creates fresh materials for it.

This implies that "not only is the scale of reproduction materially extended, but the production of surplus-value increases more rapidly than the value of the additional capital".

Being equal to increased exploitation of natural wealth resulting from the simple act of increasing the pressure under which labour-power has to operate, science and technology give capital a power of expansion which is independent of the given magnitude of the capital actually functioning.

Actually, "science and technology", with the assistance of labour's capacity for intensification, is here portrayed precisely as the subject-object unity mentioned above.

\section{A System of Nation-states? Misconceptions of the "Polity"}

Let us now, as observant, not all-too-naive insects, fly over into the next spider's parlour, Fraser's conception of the political field; the latter ought to be the primary terrain for the 
conscious operations of our subject-object. Here, the author tells us:

Also definitive of capitalism is the institutional separation of 'economy' from 'polity', a separation which expels matters defined as 'economic' from the political agenda of territorial states, while freeing capital to roam in a transnational no-man's land where it reaps the benefits of hegemonic ordering while escaping political control (Fraser, 67, italics added).

However, in a Marxian corollary, the divide between politics and economy is generated through the more fundamental split between state and civil society. Understood in this way, and only thus, is it "definitive" of capitalism. It belongs to the essence of the latter, but only because it is developed from the antagonism between money and commodities. As Leo Trotsky pointed out, the state is a parallel to money, showing how "class society, ... to defend itself has put into action the most terrible of all fetishes, the state, with a large knife between its teeth" (Trotzki 36, cf also Rosdolsky 1968, I, 161). Just as 'natural' as money, itself a commodity, separates itself from "the common commodity-mob (Warenpöbel)" (Marx), so the state is generated 'naturally' through the diverging, yet identical money-commodities interests of every market-related owner or producer in bourgeois society. It is a consequence, also, of the split of each and every person in bourgeois and citoyen, as seen by Marx in his critique of Hegel's Philosophy of Right (cf Sandemose, 2008).

This does by no means expel the state from economic affairs, nor does it generate a belief that it should not partake in such action; it just implies that it acts in the economic field as an undisputed monopolist of power. Fraser is a victim of gross misconceptions when she believes that the "definitive" split in society is an immediate factor of power for democratic opposition against the state:

Likewise, practices oriented to polity, as opposed to economy, often refer to principles of democracy, public autonomy and collective self-determination, however restricted or exclusionary these may be.

The real point lies in understanding that such action - which politically considered is at most reforming or reformist - is doomed to take place inside the "fetishized", alienating relation between politics and economy. Like we saw in an example used above: What defines capitalism, is that changes take the form of latent or manifest functions for the ruling system. Fraser's picture is, as before, the one we meet in the empiricist - isolated from catching, and unable to grip, the overarching, basic synthesis behind the sensuous phenomena.

An example is state action like the British Factory Acts late in the 1840's, which put a great number of unserious capitalists out of business, because their profits were to low to finance the extra expenses following upon implementation of the laws: Consequently the statal action had to function as a locomotive in concentration and centralisation of capitals. On the whole, state action based on class interests of workers are with necessity transformed into advantages for capital in general. There is no way of getting off this hook, just as there is no reason for the workers to abstain from initiating such action. The point is getting the matter clear and take a conscious stand to it: The action in last resort has to be a revolution - which can be defined as the only act without a "function" for bourgeois society.

Such examples illustrate very well how so-called "welfare states" (an absurdistic term) is nothing but systems for effective exploitation of the working class, while the instruments 
of "welfare" are of course also to relative advantage for the exploited. The same goes for most of those institutions which theoreticians like Fraser take to belong simply to a background of communities giving life-blood to the capitalist order; they are in reality products of capital itself, not to speak of the fact that on the material side they exist in an ambience stuffed with monstrous collections of fetish-bearing commodities ushering from capitalist production.

Now, as we pointed out above, Fraser's concept of the "polity" is expressed in terms so vague that it leaves undecided the question of her view on the possibility of applying the state/society contradiction on an international scale.

Still, this passage may contain the master key to her views:

Here we find further structural divisions that are constitutive of capitalist society: the 'Westphalian' division between the 'domestic' and the 'international', on the one hand, and the imperialist division between core and periphery, on the other - both premised on the more fundamental division between an increasingly global capitalist economy organized as a 'world system' and a political world organized as an international system of territorial states (Fraser, 64).

However, in a Marxian view, any Westphalian division is bound to be taken as a product of capitalist national economies existing in the plural (two or more), making up a "world market". The bourgeois state appears as a nation-state, and sublates the contradictions between internal capitalists by guaranteeing a currency whose value is a function of the average intensity and productivity of that nation's labour force. On the world market, we thus have the original situation of an exchange of commodities at weighted average values, not at capitalist prices of production (Note 6). Thus at bottom, these nations are still related to each other as individual commodity owners of the early capitalism of Hugo Grotius: On the world market, their position is like the one of the "state of nature", and lawlessness is fundamental.

Consequently, it can be said already that Fraser, with her contingent explanation of the schism between state and society, is not on the frequence of Marxian theory in this matter, albeit it is declared to be her negative departure-point.

The contention that there exists a capitalist "world system", not to speak of a global economic structure that warrants concepts like "core" and "periphery", is not underbuilt in the least by Fraser. This fact surely is apt to raise doubts about the degree of substantiality of her views. Is she simply copying popular viewpoints inside the academic left?

Still worse: To the extent that Fraser's world picture encompasses the whole geopolitical area characterized by market relations, however provisional, weak or faint they might be, it will a priori impress a sketch of capitalism that is all too mosaic and heterogeneous. If she actually believes that we have to do with the same type of capitalist enterprise, or private property, in the West as e.g. in Russia, where private property of soil scarcely does exist east of the Karelian Isthmus, then it is clear that we will not easily recognize ourselves in the portrait she draws. On the other hand, it becomes a lot clearer how she is able to play down the differences between modern Western society and a social formation like feudalism. In the dark, all cats are grey.

\section{Empiricism as Reformist Ideology}


If a social theory is a body of thought about what cannot be perceived concretely, it has to contain certain judgments on what can only be thought, or rather, what Marx called Gedankendinge. As a social theory, it contains sentences which it takes to be present in a uniform way amongst members of a group. It then also studies the way in which such thoughts are present - as enforced, or as by association, or by custom only, etc. In short, the theory looks up connections between people which are not openly revealed.

The Marxian theory is a body of thought of such kinds, and has concluded that actual categories which take the form of alienated things are in fact forcing us to act according to coercive patterns. These are unsensible relations. To have a theory about them must include that one is conscious about the method of analyzing them, and in what way one must delimit the analysis, i.e. understand its field of validity.

In so far, one can construct a picture of society that seems internally consistent and where the parts are self-relying in interaction. Then it has become legitimate to pass over to action - to change the relations which are unseen, but which one now takes for granted.

And here, there is no legitimate room for spontanism. One acts according to plans gushered from the theory. If one has analyzed interaction between workers at a certain workplace, with the prospect of proposing a way to liberating action amongst them, one does not change one's mind simply because one happens to see a woman washing dishes in a workingman's kitchen - even if one is a feminist.

The capital relation has its origin in a certain typus of ownership. The latter cannot be smelt, seen, heard or felt, but can be deduced by understanding, through observation of customs and behaviour. Kinds of care, provisioning, housing locations, body movements, etc. are amongst the observable entities that may lead us to conclude that a non-sensible relation called ownership does exist. Now, if capital - or for that matter, ownership in general - cannot be observed directly, neither can those entities be perceived without mediation. Still, in putting them in relation to capital, to which theoreticians may (all according to personal taste) subordinate them or rectify them, we learn something about our own tastes as regards concept formation. A scientific analysis is fully justified not to start with any preference when it comes to search for the relative importance of specific, identifiable human relations. Yet, that investigation should not exclude the possibility, indeed the probability, of finding an inert hierarchy of such activities.

To take an adjacent example: "Care", just like "capital", is a relation between people, expressed through material things. In this case, it may be things like sweet gifts or ferrous whips, or even entities like flesh and blood. But as relations, they do not take on any enduring, socially mystified form inside these things. They are conceptualized rather like iron pieces or sugarloafs - conceived as things with natural properties. Say that we want to check the weight of a thing. If we use a piece of iron to express the weight of a sugarloaf, we might be tempted to compare that operation with an exchange of two products. But soon, ... the analogy comes to an end. In the weight-expression of the sugarloaf, the iron represents the natural property of weight, which is common to both things, while in the value expression of the linen, the coat represents a supernatural property: their value, something purely social (Marx, 1969, 71). 


\section{MInstitute Macrothink $^{m}$}

This lack of mystification pertaining to natural expressions of relations can without difficulties be extended to social relations in great generality. Weight is a natural relation whose expression is actively and fully consciously sought for from case to case, and consequently it offers no mysteries or alienations. In the same manner, "care" is in itself a natural activity whose expressions in pleasure or well-being can be identified and differentiated, without losing its natural character of being what we recognize as "care". The possibility of mystifications is even less than in the former example, since there is no need or possibility of measuring the kinds of well-being against each other (pace utilitarians).

In the case of the value relation, however, the material of the expression, here: the iron, in more developed forms: the gold, takes on the form of an equivalent, because it also invites the mystification of representing value tout court, i.e., even outside the measuring relation. In the relation between sugarloaf and iron, "iron counts as a body which presents (darstellt) nothing but weight" (ibid). But this goes only in concrete, practical situations 'in the weighhouse'. Nobody looks at any material as an incarnated 'form of weight', but nonetheless such a reversal of natural relations actually takes place in exchange, and develops to the golden money fetish.

This is the genesis of 'capital as a subject'. The consciousness of the individuals are forced into a reversing position, and the power of their subjectivity therefore turned into giving up this self-same subjectivity to capital (Note 7). Consequently, capital is "subject". This takes the form of general reality, but it cannot take this form unless the subjectivity of individuals, especially as wage labourers, keeps on working in a continuous, steady way. The proletarian class-consciousness remains, but in the form of producing its antagonist. This, rather than Fraser's interpretation, seems to me to hit the core of Lukács' work mentioned above.

Also, proletarian class-consciousness measures itself up against other, specific class-consciousnesses in capitalist society - capitalists', landowners' and the petty bourgeois one - and in this concreteness forms part of the general class struggle in that society. In practice, this implies that a criticism of Fraser's wiews should include her narrow interpretation of class struggles at large. De facto, and as we have seen, she reduces them to "struggles over control of commodity production and distribution of surplus value". But these are, again, just names put on aspects of conflict which more or less regularly reach the social surface. The deeper structures of class antagonism are not so easily accounted for. In her usual empiricist vein, Fraser ignores the overarching synthesis active in the thought-forms of the consciousness of members of diverse classes. She ignores the actual motives of classes that are fighting against "neoliberalism" for reactionary purposes, and seems to think that such a fight cannot be upheld without a "progressive" motivation.

Now, traditionally, empiricism met with a crucial obstacle in rationalist (Leibniz) and criticist (Kant) objections, to the effect that it unwittingly is dependent on a presupposition of a conscious subject that recognizes the empirical appearances as belonging to an identical self. In later idealism (Hegel) this was fortified by the assumption that those appearances, as well as that subjectivity, have their condition of possibility in the labour (Arbeit) and work (Werk) of the individuals.

German Idealism, for reason of logical consistency, had to widen the question to focus on the conditions of possibility of the one subject cognizing (and consequently recognizing) the 
other, thus leading epistemology to concentrate not only on outer nature. This, again, was widened to a thesis that experience of appearances was possible only through a thoroughgoing intersubjectivity. Through Marx's Auseinandersetzung with this idealism, with an analysis mediated by concepts with provenience from Spinoza (cf e.g. Marx, 1953, 358 sqq), it becomes fairly clear that he takes the capital relation to be the necessary intermediate joint between social formations based on landownership, and the collective ownership of communist society.

Actually, for Karl Marx the 'capital as subject' is the subjectivity of all individuals, as a totality, in a society dominated by the capitalist mode of production. It is a result of a collective work under capital, and is consequently an alienated and abstract forerunner of the construction of the humane version of the "substance as subject", which Hegel meant to anticipate.

This, in its turn, implies that the subject which in the process of cognition serves as the guarantee that every empirical appearance belongs to one and the same individual, actually stands for the dominant form of production itself. In its contemporary shape, that form sets itself through as repression and enforced uniformity amongst the masses. Still, its content is well worth to cling to.

One may think otherwise, unless one is already conscious of the Marxian theory of capital as subject qua self-processing value. In that case, it is a severe self-contradiction to go after empirical structures of social action ("care", "polity", "labour at the point of production", etc.) in the hope of finding a surrogate for capital.

In fact, Fraser has beforehand thought out a standpoint which allows her to grip any empirical manifestation of capital, interpret it without showing much care for the fetishized structure in which it presents itself, and select it as a basic "abode". In some cases, the selection seems to be based on spontanist embracing of apparently heroic activities towards which she already has a leaning; in other cases, it is even impossible to find the tiniest attempt to set up a conceptual groundwork.

Fraser's de facto theoretical sublation of 'capital as subject' makes a revolutionary political action unthinkable - all the more so, as she misunderstands the role of "polity" in Marx's theory. What is left, is a reformist action in the hope of amending the human condition - a praxeis that Marx found to be "Donquixoterie".

\section{References}

Fraser, N. (2014). Behind Marx's Hidden Abode. For an Expanded Conception of Capitalism. New Left Review, 86, 55-72.

Marx, K. (1953). Grundrisse der Kritik der politischen Ökonomie. Berlin: Dietz.

Marx, K. (1969). Das Kapital, Band I. Frankfurt am Main: Europäische Verlagsanstalt.

Marx, K. (1969a). Das Kapital, Band II. Frankfurt am Main: Europäische Verlagsanstalt.

Rosdolsky, R. (1968). Zur Entstehungsgeschichte der Marxschen ,Kapital' (I-II). Frankfurt: Europäische Verlagsanstalt. 


\section{Macrothink}

Journal of Social Science Studies

ISSN 2329-9150

2016, Vol. 3, No. 1

Sandemose, J. (1976). Ricardo, Marx og Sraffa. Copenhagen, Lund, Oslo: Rhodos, Bo Cavefors, Gyldendal.

Sandemose, J. (2001). The World as a Game in Sraffa and Wittgenstein. A case study in modern bourgeois ideology. Research in Political Economy, 19, 173-231. http://dx.doi.org/10.1016/S0161-7230(01)19008-5

Sandemose, J. (2002). Stat, religion, økonomi: Karl Marx og kapitalismens former. Oslo: Gyldendal.

Sandemose, J. (2008). Modern Eleusis: Religion and Factory. Science \& Society, 72(3), 266-294. http://dx.doi.org/10.1521/siso.2008.72.3.266

Sandleben, G. (2008). Zu Fragen der Modifikation des Wertgesetzes auf dem Weltmarkt. Berlin: Internet.

Schmidt, A. (1962). Der Begriff der Natur in der Lehre von Marx. Europäische Verlagsanstalt, Frankfurt.

Trotzki, L. (1957). Die verratene Revolution. Zürich: Veritas-Verlag.

\section{Notes}

Note 1. http://newleftreview.org/II/86/nancy-fraser-behind-marx-s-hidden-abode

Note 2. Especially Schmidt 1962

Note 3. Importantly, these themes were further elaborated in the French edition (1872) of the work. Probably, much of the reasoning has to do with the rise of "the second industrial revolution" which started at the time, and which quickly made itself felt by a great advance in the physical durability of fixed capital

Note 4. The equally incontestable fact that the capitalist receives long-term compensation for wear and tear on machinery, is not weakening this point, where the momentaneous effect of machinery is the theme. Besides, as we shall see in a moment, there are introduced other factors which grant capitalists other no-charge-benefits from concrete labour and its products.

Note 5. The point is taken up again in Volume II of Capital, with modifications for phenomena of the process of circulation. See Marx 1969a, 38.

Note 6 . The best extant overview and study of Marx's theory of international values is to be found in Günther Sandleben 2008.

Note 7. Here, one clearly sees the perverting role of contemporary ideas of concrete forms of consciousness as a "capital" of the individual. 


\section{Macrothink}

Journal of Social Science Studies

ISSN 2329-9150

\section{Copyright Disclaimer}

Copyright reserved by the author(s).

This article is an open-access article distributed under the terms and conditions of the Creative Commons Attribution license (http://creativecommons.org/licenses/by/3.0/). 